\title{
Young Women, Sexuality and Protestant Church Community
}

\author{
Oppression or Empowerment?
}

Sonya Sharma

UNIVERSITY OF BRITISH COLUMBIA

ABSTRACT Although Christianity's clout on sexuality has generally declined in Britain due to secularization, contemporary conservative Protestantism continues to encourage a conventional construction of sexuality - sex is only for the context of heterosexual marriage. Qualitative interviews with 26 heterosexual women and two lesbian women on how their Protestant church involvement impacted their sexuality revealed the pervasive discourse of a marital-confined sexuality and participants' sense of 'accountability' to the group for carrying this out. Such accountability can result in a repressed sexuality that is oppressive. Alternatively, it can produce a 'sense of community' that functions as a source of empowerment. The oppressive and empowering nature of accountability, however, can be difficult to untangle because of women's religious commitment and supportive friendships found in church life. Relying on participants' accounts, this article addresses the oppression and empowerment young women experience when they negotiate their gendered identities in relation to a marital-confined sexuality.

KEY WORDS accountability $\bullet$ femininity $\bullet$ policing and sexuality $\bullet$ Protestant church community

I think the church culture says that you need to take dating very seriously. You can't mess each other around. Respect each other. In the experience of my friends, it is your close friends keeping you accountable and who have every right to be talking to you and keeping you accountable . . . it's like a fish bowl. (Hannah, age 27, Baptist, attends church) ${ }^{1}$

In the contemporary West, conservative Protestantism continues to encourage the notion that sex is only for the context of heterosexual marriage

European Journal of Women's Studies Copyright (C) 2008 SAGE Publications (Los Angeles, London, New Delhi, Singapore and Washington DC), 1350-5068 Vol. 15(4): 345-359; http:/ / ejw.sagepub.com DOI: 10.1177/1350506808095274 
(Aune, 2002; Moon, 2004; Ruether, 2000; Sharma, 2007). The community's construction of sexuality is well known, seen in the recent debates over whether to ordain homosexuals and bless same-sex unions. ${ }^{2}$ Other Christian approaches that espouse this construction have been evangelical initiatives like Alpha for new Christians or abstinence youth movements like True Love Waits and The Silver Ring Thing (Asthana et al., 2004; Hunt, 2005; Winner, 2005b). ${ }^{3}$ Although Christianity's clout on sexuality has generally declined in Britain due to the process of secularization (Brown, 2001), contemporary conservative Protestantism continues to encourage and teach a marital-confined sexuality (Aune and Sharma, 2007; Sharma, 2007).

Significant to understanding sexuality in conservative Protestantism is its construction of gender, shaped by 'compulsory heterosexuality' (Rich, 1980). Heterosexuality is 'a category divided by gender and which also depends for its meaning on gender divisions' (Richardson, 1996: 2). It is a structural mainstay of conservative church life. Jackson (2006: 105) writes, 'institutionalized normative heterosexuality regulates those kept within its boundaries as well as marginalizing and sanctioning those outside them'. It orders not only one's sexual life, but also domestic and extradomestic divisions of labour and resources (van Every [1996] and Ingraham [1996], cited in Jackson, 2006: 107). Important to the success of normative heterosexuality is the conservative gendered constructions of femininity and masculinity. Rooted in the work of sociologist R.W. Connell (1987: 188), 'emphasized femininity' is a social practice that is organized in response to men's power and underscores compliance, nurturance and empathy as womanly virtues. It is not dominant among other femininities, but marginalizes other forms and remains subordinate to hegemonic masculinity, which is always constructed in relation to various subordinated masculinities as well as in relation to women. Conservative Protestantism 'considers subordinate femininity and sexual passivity vital to women's sexuality, which can only be expressed in marriage' (Aune and Sharma, 2007). ${ }^{4}$

When interviewing young women on how their Protestant church involvement impacted their sexuality, the discourse of a marital-confined sexuality was pervasive. This discourse was linked to a 'Christian femininity' in which married heterosexuality, chastity ${ }^{5}$ and appropriate conduct and body presentation (for example how young women dress) were key aspects, and very much tied to participants' Christian beliefs and values. I liken this femininity to Connell's (1987) emphasized femininity. Evident in participants' interviews were the ways that a Christian femininity provided the boundaries for how young women conducted themselves in relation to sexuality. This became apparent when young women discussed being 'accountable' to the group for carrying out the church's construction of sexuality. 
Accountability in church life is the emphasis not on the self, but on the worship of God and on communal bonds (Miller, 1997: 151). It means a commitment of faith and a commitment to the church community, to its beliefs and values. British theologian Martyn Percy, who has written on and researched contemporary Christian culture (Percy, 1996), and British researcher Tony Watling, who has studied people's experience of the Alpha programme, a Christian evangelizing ministry, have found that when people make a new commitment to believe in Jesus Christ, believers new and old come together to form a community. 'They learn to interpret events "in common", using communal meanings to engage in the world. It is also where they can be monitored and "guided" by being encouraged to interpret events, articulate feelings, act the "correct" way and be held accountable' (Percy, 1996, cited in Watling, 2005: 103).

Hannah, in the opening quotation to this article, discusses the kind of accountability to which Percy and Watling refer. Her peers - always within their reach and under their gaze - surround her. Based on the writings of Michel Foucault $(1991,1999)$, particularly in relation to the Panopticon and self-surveillance, the accountability experienced by church members, in Foucauldian terms, is a disciplining force that shapes one's behaviour through frequent observation and assessment. Bartky (1990), who critiques and applies Foucault's work, argues that while women are subject to many of the same disciplinary practices as men, the disciplines embodied by women are markedly feminine. Protestant church culture is one place where young women reproduce a conservative femininity in their behaviour and often do so in response to particular expectations about what is appropriate, normal and acceptable female comportment and sexuality (Bartky, 1990 and Bordo, 1995, cited in Tolman, 2002: 54). Indeed, monitoring women's behaviour, particularly related to anything sexual, in church life can be seen as an attempt to keep separate young women's identities as Christians, on the one hand, and as embodied sexual women, on the other hand. The sense of accountability that many young women find in their churches often encourages a passive and limited sexuality that can be oppressive, denying the rich diversity of sexual experiences and relationships experienced by men and women both within and out of church life today. However, such accountability can also produce a 'sense of community' and function as a source of empowerment, offering young women an alternative context to mainstream cultures that often declare sexuality integral to youth. The oppressive and empowering nature of accountability, however, can be difficult to untangle for young women because of their religious commitment and supportive friendships in an ecclesiastical context. Relying on young women's accounts, in this article I address the oppression and empowerment young women can experience when they negotiate their gendered identities in relation to the Protestant church community's construction of sexuality. 


\section{METHODOLOGY}

Thirty-six women were interviewed for this research. Participants are from mainly white, heterosexual, British, middle-class backgrounds. Those who are of British origin or who were living and attending church in Britain at the time of the interviews (28) are the focus of this article. ${ }^{6}$ Of the sample, 26 identified as heterosexual and two identified as lesbian. ${ }^{7}$ The interviews took place over a 12-month period (2004-5) and were semi-structured and conversational in style. Questions were open-ended, and divided into sections on church involvement: its impact on participants while growing up, its affect on sexual matters and how it impacted their voice as a young woman. I approached my analysis by examining the data I had gathered from participants as narratives. This allowed me to study thematically the situated and locally produced cultural accounts of participants' stories (Silverman, 2000). Throughout the research process I opened and immersed my self to the experiences of my participants, gathering insights into their narratives through listening deeply, being patient, contemplative and reflexive (Crabtree and Miller, 1999). Being attuned to my emotions during the interviewing process also gave me a rich account to consider, as emotions illuminate another way of seeing (Bennett, 2004). Rereading and re-examining the stories told by participants, I was able to draw out common themes from their narratives.

The denominations represented among participants are Anglican (11), Baptist (9), Methodist (4) and interdenominational (4). ${ }^{8}$ I use the term 'church community(ies)' to refer to Protestant congregations in which women are involved and more widely to the culture of conservative Protestantism that includes, for example, Sunday services, weekly Bible studies, popular Christian music and literature, youth organizations and ministries. These promote a common Christian identity - a personal relationship with God and a commitment to the community's values. Not all participants continue to attend church regularly. Some are irregular church attendees (5), while others have left church (4). Many women in the study remain faithful churchgoers (19). ${ }^{9}$ Although participants in this research are from a mixture of Protestant denominations, allowing me to draw wider conclusions, most young women described being engaged in a conservative evangelical Protestantism. Many gave accounts of believing in the authority of the Bible and the divinity of Christ. They described their churches as oriented towards contemporary styles of worship, Biblecentred teaching and preaching, evening services for young people and community outreach through evangelical initiatives like the Alpha programme (Miller, 1997). Even though each denomination gives their own level of attention to sexuality, due to the often conservative nature of their churches many young women were exposed to the teaching of a maritalconfined sexuality. ${ }^{10}$ 
All interviewees attended church between the ages of 18 and 25. I focus particularly on this age period, even though many young people are engaging in sexual activity earlier, because it is an age range when they are experiencing transition into adulthood and independence (Clark, 2000; Kundu and Adams, 2005). I wanted to know how young women negotiate their involvement in church community and its construction of sexuality while engaged in other social contexts (i.e. higher education, employment and travel) that often convey more liberal messages for sexuality (Carpenter, 2005; Levy, 2005). Although some young women carry the values of their families with them and may still be living in the family home, the family becomes less central to their personal formation compared to wider influences (Kundu and Adams, 2005).

I also draw on interviews with women older than 25 . This allowed me to consider how their church involvement affected their growing sexuality during these ages and beyond, even though they have been shaped by different histories and contexts. The older women add a different voice and dimension. The aim of this study was not to compare the experiences of older and younger women or denominations, but to understand how women's church involvement and its teaching impacted their sexuality.

\section{THEORETICAL FRAMEWORK}

My analysis of young women's lived experiences of sexuality and church community is informed by the theories of feminist psychologists who have studied young women's identity development (Gilligan, 1982; Jordan, 1997; Miller, 1976; Surrey, 1991). Central to their work is the notion that women develop through connection and relationship, not through the stages of independence and autonomy, which are male-centred (Wastell, 1996). They agree that the process of identity formation takes much longer than is allowed for in 'stage' theory (Erikson, 1968; Levinson et al., 1978) and believe relationship is the basis for self-experience and development, with other aspects of the self (e.g. creativity, autonomy, assertion) developing within the primary context of 'self-in-relation' (Surrey, 1991: 53).

The age period 18-25 is therefore a time when young women's growth of the self is 'continuously being formed in connection with others and inextricably tied to relational movement' (Jordan, 1997: 15). Close-knit church communities are relational systems that give women structure and support for confronting the various life and identity issues that may arise during this age period. Here, not only is 'Community created in relation to identities, identities are molded through community involvement' (Abrahams, 1996: 786). However, the 'community' that moulds young women's identity formation can also inhibit self-growth in areas such as sexuality. In my analysis, I also rely on the work of Foucault $(1991,1999)$ 
and feminist theorists (Bartky, 1990; Holland et al., 1998; Kelly, 1988; Lees, 1997) to help illuminate how the accountability to church community and its gendered construction of sexuality can also shape and limit behaviours and experiences. Among members, it is a construction to which many women believe they have to adhere, often resulting in self-scrutiny and the monitoring of one another. Thus, church community that fosters growth in connection can through the very same relationships hinder sexual exploration and development because of the notion of accountability. Based on participants' accounts, what follows is an analysis of their experiences of community accountability to live out a marital-confined sexuality, which can be, depending on the context, oppressive and empowering.

\section{SEX AS A COMMUNITY DECISION}

Young women's sexual and relational selves that are informed by regular church participation and peer relationships can frequently mask conditions of oppression of which women may not be aware. Because many young women believe they are accountable to their churches, sexual decisions are sometimes felt not to be theirs; rather there is a sense that their sexual self belongs to the community. Patricia told me:

The personal decision to have sex is an oxymoron in the church. You don't have a personal decision about sex and so you don't think about it in that way, you don't think that it's yours, you think that it is a society decision. (Age 28, Baptist, in between finding a church)

'Relationships of accountability in the Christian community are very important if we are to maintain the standards of purity and integrity which Christ demands of us' (Gladu, 1995: 10). This quotation from a leader of a university campus ministry emphasizes the responsibility church members have to one another to keep a marital-confined sexuality; hence a difficulty is presented when one is or wants to become sexually active, as Patricia eloquently explains. Christian author Lauren F. Winner writes: 'The place where the church confers the privilege of sex is the wedding; weddings grant us license to have sex with one person ... sex beyond the boundaries of marriage - the boundaries of communally granted sanction of sex - is simply off limits' (Winner, 2005a: 123-4). She further states, 'Sex is communal and Christians have an obligation to talk to each other about sexual sin' (Winner, 2005b: 59). Patricia's decision to have sex is consequently not about her or the responsibility she has to her own desires; it is a community decision.

This is not unlike what Foucault (1999) refers to when writing on Christianity, which he perceives as having two kinds of 'obligation': first, the obligation to hold true the faith and the book (the Bible), 'which 
constitute dogma' and second, to the self, the soul and the heart. Both are linked together, but the second requires one to 'explore who he is, what is happening within himself, the faults he may have committed, the temptations to which he is exposed. . . everyone is obliged to tell these things to other people, and hence bear witness against himself' (Foucault, 1999: 182-3). It is a spiritual struggle against impurity of thought and to protect him- or herself, the individual needs to confess to others, submit to their advice and accord obedience to his or her superiors (Foucault, 1999). He or she learns and carries out the rules of moral sexual behaviour, and scrutinizes him- or herself in order to keep the obligation to the faith and its community (Foucault, 1999).

\section{POLICING SEXUALITY}

Such obligations, however, have implications for young women, especially when their faith experiences are entangled with the community's often-gendered expectations, which can have a disciplinary effect (Bartky, 1990). Young women discussed the sense of being monitored by others, self-scrutiny and not disclosing sexual events for fear of being judged. Victoria said, 'I think what my friends and I were doing [was] policing each other's behaviour and helping each other to be Christian women, as we thought we ought to be' (age 29, Anglican, in between finding a church). Feminist researchers (Holland et al., 1998; Kelly, 1988; Lees, 1997) have examined the policing behaviour that happens among young women and men in relation to hegemonic masculinity and traditional femininity. Policing behaviour, as it is understood from this body of research, is to watch, monitor, supervise, scrutinize and oversee one's own and another's behaviour (Radford, 1987, cited in Kelly, 1988: 33). It is both behaviour and discourse that keeps normative heterosexuality and conventional modes of masculinity and femininity in place. Many young Christian women police each other according to the community's construction of gender and sexuality. For example:

There is a sense in the Christian community, a kind of pressure to remain accountable, like being at a nightclub with Christian friends and wanting to talk to a guy and stuff, and feeling a sense of not being able to do so without getting called on it. ... You are being held back by the force of the community. (Linda, age 22, Anglican, attends church)

Linda's involvement in her Christian community - and her resulting sense of accountability - means she thinks not only about herself when negotiating sexual behaviour, but the watchful eyes, words and actions of her Christian peers. Her narrative is not unlike what sociologist Trevor Welland found in his study of students training for ordination in a residential setting, where 
'students and staff watched and judged each other' (Welland, 2001: 79). Linda internalizes her peers' gaze, self-scrutinizing her behaviour to uphold her community's values and her place within the group.

Because of the 'force' of the community, some young women did not share anything about sexual events with church peers, but kept them hidden. Grace explains:

People who seemed, like, knowledgeable about everything religious, who then tell you that something is wrong, definitely made me feel guilty, but the problem was in feeling guilty meant that I felt I couldn't talk to anyone about it. So I kept quiet and pretended it hadn't happened. . . . I definitely felt that you couldn't go and tell people what you were doing, if you were having sex while in the church or tell somebody who you went to church with because they would look down on you and judge you. (Age 20, Methodist, attends church)

Unfortunately, the close relationships and sense of belonging forged through church communities can also perpetuate and enforce feelings of guilt in relation to one's identity as a young sexual being. In not telling her friends, Grace gives the impression of being accountable. She 'keeps large parts of her experiences and responses out of connection in order to try to find or maintain connections' with others (Miller and Stiver, 1997: 82). Grace pretends her sexual experiences did not happen in order to be acceptable and accepted, as 'a woman's sexuality is central to the way she is judged and seen' (Lees, 1997: 11).

Linda and Grace's accounts speak to the disciplinary power of a conventional femininity found in conservative Protestant church culture. As patriarchy has taken on new forms of domination in the public sphere, young women have become like 'the inmate in the Panopticon ... a self committed to a relentless self-surveillance ... a form of obedience to patriarchy' (Bartky, 1990: 80). Linda and Grace wear the mantle of responsibility for sexual episodes demonstrated in the way they police their bodies and voices, not acting on sexual desire and staying silent about sexual activity. Coopted by the patriarchal sex agenda, they become complicit in their own oppression, supported by their church communities to repress their sexual subjectivity.

\section{SEX IN MARRIAGE IS 'SPECIAL'; 'I FEEL FREE WITHIN THAT CONTEXT'}

The Protestant church culture's marital-confined sexuality and the boundaries it provides and are kept by its members are for many women welcomed. There is a 'freedom' in being accountable, even though women are aware of the patriarchy in organized religion (Ozorak, 1996). During the 
interviews, some young women told of converting to Christianity between the ages of 18 and 25, a time when they were attending university, an environment that offers options and opportunities for sexual expression, which can be a pressure. For these young women, choosing to have sex in marriage is tied to the confidence they have in the boundaries set by their Christian faith, to their belief in the plan God has for their lives and to the support they receive from their church peers. Lisa told me:

When I first became a Christian I struggled with it a bit because I had had sex and I thought, 'oh they're not going to have anything to do with me', but I think realistically it's not like that, and although some of the church teachings about it are wrong, like I am not sure that God needs to necessarily forgive the fact that you have already had sex. I can totally see now the teachings make sense and I think ideally it should be kept until marriage and I think the church is a bit wrong in condemning people that don't fit in with its ideal. But I do think, agree with the teaching. . . .Um, well I haven't had sex since I have become a Christian and that is the main thing, really. I guess I have much more respect for it now, because beforehand it was more just really, more just part of culture or life, really. But I think being a Christian you put much higher values on it, so it has become something much more important and it's become something much more like necessary, like before I viewed sex as something just kind of physical I think now it's much more important, necessary, it's more special I guess. (Age 22, Baptist, attends church)

Lisa discovers her faith for herself and shows boldness in accepting a counter-secular view on sex. Harriet concurs, 'I see sex as something that should be saved for marriage, and is very special and for marriage. I have never really thought that I want to do it before' (age 19, Anglican, attends church). Adhering to their churches' construction of sexuality provides them with a sexual identity to hold fast to in popular cultures. It gives them a form of femininity that can offer a structure they desire in the face of mainstream femininity that often endorses sex and sexiness as the way to be feminine. A conventional femininity gives many a recognizable place within heterosexual relations and a public identity in relation to other women (Holland et al., 1998: 133). Journalist Jenny Taylor, a celibate Christian, writes: 'The relief for me was to discover there was such a thing as a Christian sexual ethic, and on converting to Christianity, to discover that for the first time in my life I had a source of strength not my own, with which to say "no"' (Taylor, 2004: 12). Mina agrees, 'My Christian beliefs and values dictate how my sexuality is used . . . I don't feel oppressed, I actually feel free within that context' (age 24, Baptist, attends church). Women today face competing representations of femininity because of women's changing identities since the 1960s, leaving many women wondering what it means to be 'feminine' (Woodhead, 2008). Today's society, which allows for multiple perspectives and identities to 
exist, means young women can possess a Christian feminine identity that supports a conservative stance on sexuality. The pressure found in sexualized mainstream cultures is for many Christian women not a pressure at all because of the supportive friendships they find in their churches, leading to a sense of empowerment about sexual decisions.

\section{A CHURCH COMMUNITY THAT FITS HER SEXUALITY}

Sustaining such accountability, however, can be a huge constraint for some women, resulting in their disaffiliation. Some found that they could not conform to a conventional femininity and sexuality and therefore left in order to embody their sexuality in a way that fit with how they knew themselves to be growing as sexual and relational women. Others transformed their church's theology. For these lesbian women, understanding how heteronormativity marginalizes can be empowering. Victoria said:

At one point I did aspire to [marriage] and [felt] that was what God wanted for my life. I desperately wanted a husband from age 20 till about 22 or 23, but not that it suddenly stopped, maybe 24 , and carrying on after that probably for sometime. ... Definitely my Christianity defined my sexuality, and also defined it as heterosexual. I didn't have an issue with it. It was fine, and I didn't fancy women. It was only when I was about 22 when I questioned that aspect, when I [finished university] . . . so the break when I left church, that's interesting. The two breaks I had from church have been really significant in terms of my sexuality because leaving the fundamentalist church is when I started to feel attracted to women and then later when I had the year out from church was when I actually finally decided I was going to have a relationship with a woman, that was the way I was going to go and I couldn't have done that in the church because the church community was too close knit for me to have been able to create a new life for myself and go to gay groups or whatever. So, I had to come out of [church] to make that decision. I think not going to church is probably very important for Christian women's discovery of their sexuality. . . . Now I probably go about once a fortnight ... I need to go somewhere where there is a female vicar so then I won't have these issues about sexism. (Age 29, Anglican, in between finding a church)

Her decision to be in a relationship with a woman is not something she could have openly done while involved in a conservative Protestant church. Thapan (1997) contends that conflict, not passivity, is central to whether a woman will give expression to her desires and views. Victoria pursues the conflict within her, deciding to leave and enter into a lesbian relationship. This goes against the normative heterosexuality embedded in church communities and subverts conventional modes of femininity that are characteristic of conservative Protestantism. Like sociologist Andrew K.T. Yip (2000) found in his research on non-heterosexual Christians, leaving is not because Victoria loses her faith, but rather she is 
rejecting her church's exclusion of her. When she does return to church, she attends a congregation that is open to her sexual identity. Victoria no longer shapes her sexuality to suit traditional church life but finds a church that accommodates hers. Similarly, Angela, a 'lesbian feminist Christian', brings an alternative interpretation to her church's theology to fit her sexual identity:

For me, any sex I have is going to be before marriage because I am not allowed to get married. My view on sex before marriage came before I knew I was gay. ... I think the whole thing in the Bible about sex being procreative is completely right. It doesn't have to be a physical procreation but if it is fostering your relationship and creating new things in relationship then that form of sex is just as procreative. (Age 23, Anglican, in between finding a church)

She resists the traditional Christian view of heterosexual sexuality and adopts an interpretation that gives her freedom to negotiate her lesbian sexuality. Victoria and Angela's sexual subjectivity redefines where and how they carry out their Christian faith. It is from the tension found between oppression and empowerment, compliance and subversion, that they negotiate a different stance. This does not cause them to lose their faith, but provides a new way to express their sexuality. They are accountable to themselves and their understanding of the Christian faith.

\section{CONCLUSION}

The accountability to live out the morals and values of a conservative Protestant faith is expected of both men and women. There is an expectation that men and women will be responsible to one another, revealing to community members the true realities of the self. Foucault argues, 'the more we discover the truth about ourselves, the more we have to renounce ourselves; and the more we want to renounce ourselves the more we need to bring to light the reality of who we are' (Foucault, 1999: 183). There is an 'obligation' to confess one's thoughts and desires in relation to sexuality - to scrutinize oneself against sexual transgression. Such accountability is a personal, social and religious commitment. For many women, this commitment is entangled with gendered expectations - a Christian femininity - that can further limit sexual knowledge and experiences. While church community offers women a refuge and a distinct position amid sexualized mainstream cultures, some women find it too restrictive.

Many churches continue to insist on a chaste sexuality until a heterosexual marriage that may be woefully inadequate, remaining closed to the fruits that just, caring, respectful non-marital heterosexual and nonheterosexual sexual relationships can bring (Ellison, 1994). Feminist 
theologian Rosemary Radford Ruether argues that the church's espousal of heterosexual marriage or 'virginity to marriage' does not always mean sexual maturity or sexual well-being (Ruether, 2000: 219). Although heterosexual women's experiences are largely the focus here, it is the two lesbian women who, in their marginalization, find an 'open' space to negotiate their faith and sexuality. The heterosexual women are also making negotiations between their sexual selves and church community, often walking a thin line between oppression and empowerment.

\section{NOTES}

I am very thankful to Professor Linda Woodhead for nudging me to write, and to Dr Holly Faith Nelson and the anonymous reviewers for their valuable comments and guidance that strengthened this article.

1. All participants' names are pseudonyms. Age, church affiliation between the ages of 18 and 25 and current church status are accurate.

2. In recent years, defining marriage as that which only takes place between a man and a woman has been debated among the Anglican church of England and Canada, and the Episcopal church in the USA. These churches have experienced conflict among their dioceses on the issue of blessing same-sex unions and ordaining homosexuals.

3. The Youth Alpha programme, a worldwide Christian evangelizing initiative that has its origin in London, UK, teaches that sex and marriage ideally go hand in hand, as does the main Alpha programme (Hunt, 2005). True Love Waits asks young people to make a commitment of abstinence until marriage (www.lifeway.com/tlw/). The Silver Ring Thing is a Christian abstinence-focused organization/movement for youth and young people (www.thesilverringthing.com).

4. Marriage is being dethroned as a western ideal, but monogamy remains key to normative heterosexuality (Seidman, 2005: 59-60, cited in Aune and Sharma, 2007).

5. Chastity is 'the abstention of sexual intercourse between one person and another' (Cline, 1994: 143). Sexual intercourse in patriarchal Christianity is defined as a man penetrating a woman within the context of marriage. I use the term 'sexuality' to refer to a range of sexual desires, experiences and constructions of sexual identity, such as lesbian, bisexual or gay experience.

6. Interviewees not included are those who were of Canadian origin and living in Canada (6) or who were living in Britain, but whose main church experience had been outside Britain (2).

7. Only a small number is represented, as they were who made themselves available for the study.

8. Those who attended an Anglican church spoke of attending 'low' vs 'high' congregations, which are oriented towards more contemporary and evangelical approaches to ministry and worship.

9. Of the 36 participants, 21 attend church, 6 are in between finding a church and 9 have left church.

10. Although this research focuses on young women, the author in no way seeks to dispute or marginalize the ways in which church teachings affect young men. 


\section{REFERENCES}

Abrahams, Naomi (1996) 'Negotiating Power, Identity, Family and Community: Women's Community Participation', Gender and Society 10(6): 768-96.

Asthana, Anushka, Jamie Doward and Paul Harris (2004) 'Celibacy: The New Sex, Drugs and Rock ' $n$ ' Roll', The Observer 27 June: 12.

Aune, Kristin (2002) Single Women: Challenge to the Church? Carlisle: Paternoster.

Aune, Kristin and Sonya Sharma (2007) 'Sexuality and Contemporary Evangelical Christianity', pp. 167-79 in C. Beckett, O. Heathcote and M. Macey (eds) Negotiating Boundaries? Identities, Sexualities, Diversities. Cambridge: Cambridge Scholars Press.

Bartky, Sandra L. (1990) Femininity and Domination: Studies in the Phenomenology of Oppression. London: Routledge.

Bennett, Katy (2004) 'Emotionally Intelligent Research', Area 36(4): 414-22.

Bordo, Susan (1995) Unbearable Weight: Feminism, Western Culture and the Body. London: University of California Press.

Brown, Callum G. (2001) The Death of Christian Britain. London: Routledge.

Carpenter, Laura M. (2005) Virginity Lost: An Intimate Portrait of First Sexual Experiences. New York: New York University Press.

Clark, Warren (2000) 'Patterns of Religious Attendance', Canadian Social Trends Winter: 23-7.

Cline, Sally (1994) Women, Celibacy and Passion. London: Optima.

Connell, Robert W. (1987) Gender and Power: Society, the Person and Sexual Politics. Cambridge: Polity Press.

Crabtree, Benjamin F. and William L. Miller, eds (1999) Doing Qualitative Research, 2nd edn. London: Sage.

Ellison, Marvin M. (1994) 'Common Decency: A New Christian Sexual Ethics', pp. 236-41 in J.B. Nelson and S.P. Longfellow (eds) Sexuality and the Sacred: Sources of Theological Reflection. London: Mowbray.

Erikson, Erik H. (1968) Identity: Youth and Crisis. London: Faber and Faber.

Foucault, Michel (1991) Discipline and Punish: The Birth of the Prison. London: Penguin. (Orig. pub. 1977.)

Foucault, Michel (1999) Religion and Culture, ed. Jeremy R. Carrette. New York: Routledge.

Gilligan, Carol (1982) In a Different Voice: Psychological Theory and Women's Development. London: Harvard University Press.

Gladu, Valerie (1995) 'The Accountability Factor: How to Promote Healthy Relationships', Student Leadership Journal Spring: 9.

Holland, Janet, Caroline Ramazanoglu, Sue Sharpe and Rachel Thomson (1998) The Male in the Head: Young People, Heterosexuality and Power. London: Tufnell.

Hunt, Stephen (2005) ' "Basic Christianity": Gender Issues in the Alpha Initiative', paper presented at the British Sociological Association conference 'Religion and Gender', Lancaster University, 12 April.

Jackson, Stevi (2006) 'Gender, Sexuality and Heterosexuality: The Complexity (and Limits) of Heteronormativity', Feminist Theory 7(1): 105-21.

Jordan, Judith V. (1997) 'A Relational Perspective for Understanding Women's Development', pp. 9-24 in J.V. Jordan (ed.) Women's Growth in Diversity. New York: Guilford Press.

Kelly, Liz (1988) Surviving Sexual Violence. Cambridge: Polity Press.

Kundu, Sunanda and Gerald R. Adams (2005) 'Identity Formation, Individuality and Connectedness in East Indian and Non-East Indian Female Canadian Emerging Adults', Identity: An International Journal of Theory and Research 5(3): 247-60. 
Lees, Sue (1997) Ruling Passions: Sexual Violence, Reputation and the Law. Buckingham: Open University Press.

Levinson, Daniel J., Charlotte N. Darrow, Edward B. Klein, Maria H. Levinson and Braxton McKee (1978) The Seasons of a Man's Life. New York: Knopf.

Levy, Ariel (2005) Female Chauvinist Pigs: Women and the Rise of Raunch Culture. London: Pocket Books.

Miller, Donald E. (1997) Reinventing American Protestantism: Christianity in the New Millennium. Los Angeles: University of California Press.

Miller, Jean Baker (1976) Toward a New Psychology of Women. London: Allen Lane/Penguin.

Miller, Jean Baker and Irene Stiver (1997) The Healing Connection: How Women Form Relationships in Therapy in Life. Boston, MA: Beacon Press.

Moon, Dawn (2004) God, Sex and Politics: Homosexuality and Everyday Theologies. Chicago, IL: University of Chicago Press.

Ozorak, Elizabeth W. (1996) 'The Power, But not the Glory: How Women Empower Themselves through Religion', Journal for the Scientific Study of Religion 35(1): 17-29.

Percy, M. (1996) Words, Wonders and Power: Understanding Contemporary Christian Fundamentalism and Revivalism. London: SPCK.

Rich, Adrienne (1980) 'Compulsory Heterosexuality and Lesbian Experience', Signs: Journal of Women in Culture and Society 5(4): 1-32.

Richardson, Diane (1996) 'Heterosexuality and Social Theory', pp. 1-20 in D. Richardson (ed.) Theorising Heterosexuality. Buckingham: Open University Press.

Ruether, Rosemary Radford (2000) Christianity and the Making of the Modern Family: Ruling Ideologies, Diverse Realities. Boston, MA: Beacon Press.

Sharma, Sonya (2007) 'The Impact of Protestant Church Involvement on Young Women's Sexual Identities', doctoral thesis, Lancaster University.

Silverman, David (2000) Doing Qualitative Research: A Practical Handbook. London: Sage.

Surrey, Janet L. (1991) 'The "Self-in-Relation": A Theory of Women's Development', pp. 51-66 in J.V. Jordan, A.G. Kaplan, J.B. Miller, I. Stiver and J.L. Surrey (eds) Women's Growth in Connection: Writings from the Stone Center. London: Guilford Press.

Taylor, Jenny (2004) 'A Wild Constraint', Third Way 27(6): 12-13.

Thapan, Meenakshi (1997) 'Introduction: Gender and Embodiment in Everyday Life', pp. 1-34 in M. Thapan (ed.) Embodiment: Essays on Gender and Identity. Mumbai: Oxford University Press.

Tolman, Deborah L. (2002) Dilemmas of Desire: Teenage Girls Talk about Sexuality. Cambridge, MA: Harvard University Press.

Wastell, Colin A. (1996) 'Feminist Developmental Theory: Implications for Counseling', Journal of Counseling and Development 74(6): 575-8.

Watling, Tony (2005) ' "Experiencing" Alpha: Finding and Embodying the Spirit and being Transformed - Empowerment and Control in a ("Charismatic") Christian Worldview', Journal of Contemporary Religion 20(1): 91-108.

Welland, Trevor (2001) " "Assaults Upon the Self": Control and Surveillance in a Theological College', Journal of Contemporary Religion 16(1): 71-84.

Winner, Lauren F. (2005a) Real Sex: The Naked Truth about Chastity. Grand Rapids, MI: Brazos.

Winner, Lauren F. (2005b) 'Sex in the Body of Christ: Chastity is a Spiritual Discipline for the Whole Church', Christianity Today 49(5): 28.

Woodhead, Linda (2008) " "Because I'm Worth it": Religion and Women's Changing Lives in the West', pp. 147-61 in K. Aune, S. Sharma and 
G. Vincett (eds) Women and Religion in the West: Challenging Secularization. London: Ashgate.

Yip, Andrew K.T. (2000) 'Leaving the Church to Keep my Faith: The Lived Experiences of Non-Heterosexual Christians', pp. 129-45 in L.J. Francis and Y.J. Katz (eds) Joining and Leaving Religion: Research Perspectives. Leominster: Gracewing.

Sonya Sharma is a postdoctoral research fellow in the Family Food Practices research programme at the University of British Columbia, Canada. She is exploring how local food cultures, social class and family context interact and intersect with gender, race and culture to produce everyday food practices. She is also a researcher on the project 'The Negotiation of Spiritual and Religious Plurality in Healthcare' (Trinity Western University, Canada). Her doctorate (Lancaster University, UK) explored the impact of Protestant church involvement on young women's sexual identities. She is co-editor and contributor to Women and Religion in the West: Challenging Secularization (Ashgate, 2008). Address: Food, Nutrition and Health, Faculty of Land and Food Systems, 2205 East Mall, University of British Columbia, Vancouver, BC, Canada, V6T 1Z4. [email: sharmas7@interchange.ubc.ca] 